\title{
DANCE ON A VOLCANO: BAGANA, PAPUA NEW GUINEA
}

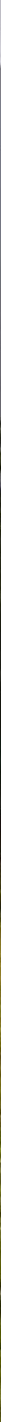




\section{Brendan McCormick Kilbride gives an account of fieldwork on an active volcano in the tropical rainforest of Papua New Guinea}

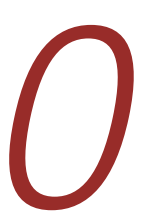

ur first glimpse of Bagana volcano was an ominous silhouette just visible through the dense rainforest covering the shore to our left. As our boat sped round the headland into a wide sweeping bay, the volcano was laid bare before us, rearing high above the coastal plains. I was in Papua New Guinea as part of an international team making a monthlong survey of gas emissions from several little-studied but highly active volcanoes. Bagana, located on remote Bougainville Island, is one of the world's preeminent sources of volcanic gas emissions and somewhere I had long wanted to visit.

\section{VOLCANIC DEGASSING}

Many volcanoes are constantly emitting gas, even when not erupting. Magma, the molten rock that drives eruptions, contains abundant dissolved water, carbon dioxide and sulfur dioxide. As magmas rise towards Earth's surface, the drop in pressure causes gas bubbles to begin growing. The ability of these bubbles to rise freely through the magma and escape into the atmosphere can strongly affect the explosivity of volcanic eruptions.

Magmas with a higher gas content tend to cause more explosive, and therefore more dangerous, eruptions.

Bagana is an interesting case. Despite its enormous emissions of gas, the typical activity of the volcano is a sluggish effusion of lava flows in eruptions lasting months at a time. Overlapping lava flows have built the main cone of the volcanic edifice, which rises 1800 metres above sea level. If present eruption rates are typical, the entire volcano could have grown in mere centuries, according to a recent study by Geoff Wadge (University of Reading), myself and others. The mystery of Bagana is how such a gas-rich volcano maintains a dominantly effusive style of eruption, with only rare shifts towards a more explosive style. To answer this question, we are drawing on a range of techniques including satellite remote sensing, measurements of gas emissions in the field, and laboratory analyses of the lava and ash erupted from the volcano.

\section{A REMOTE VOLCANO}

Our team comprised myself and Lois Salem (University of Cambridge), Roberto D'Aleo (University of Palermo), Bo Galle, Santiago Arellano and Julia Wallius (Chalmers University of Technology), and local scientist Kila Mulina, from Rabaul Volcanological Observatory. None of us had visited Bagana before, and the excitement in the team only grew as we landed on Bougainville.

Bagana is a difficult volcano to reach. In the 1980s-1990s, a bloody civil war fought over issues of secession from Papua New Guinea precluded scientific expeditions to Bougainville and even today tensions over a mooted independence referendum remain high. From Buka-the temporary capital since the previous one, Arawa, was largely destroyed in the conflict-a four-hour boat trip along the southwest coast of the island takes you to the village and anchorage of Torokina. From here, we travelled inland, bouncing around in the back of a battered old Land Rover, fording rivers and brushing through the vegetation overhanging the muddy track. Our basecamp was Gotana, a village around $8 \mathrm{~km}$ from the base of the volcano, and we were offered the shelter of a new schoolhouse under construction. Our first task on arrival was to visit the existing school, meet the Big Man and other villagers, and explain our interest in Bagana. The local children welcomed us with a song and talked excitedly of the volcano, which can be seen steaming on the horizon within a short walk from the village outskirts.

\section{A DAY IN THE FIELD}

Our tasks in the field were varied. We flew a series of drone flights over the lower slopes of the volcano, mapping the distribution and size of the lava flows with an onboard video camera for comparison to satellite observations being made by colleagues back in the UK. We also filmed 


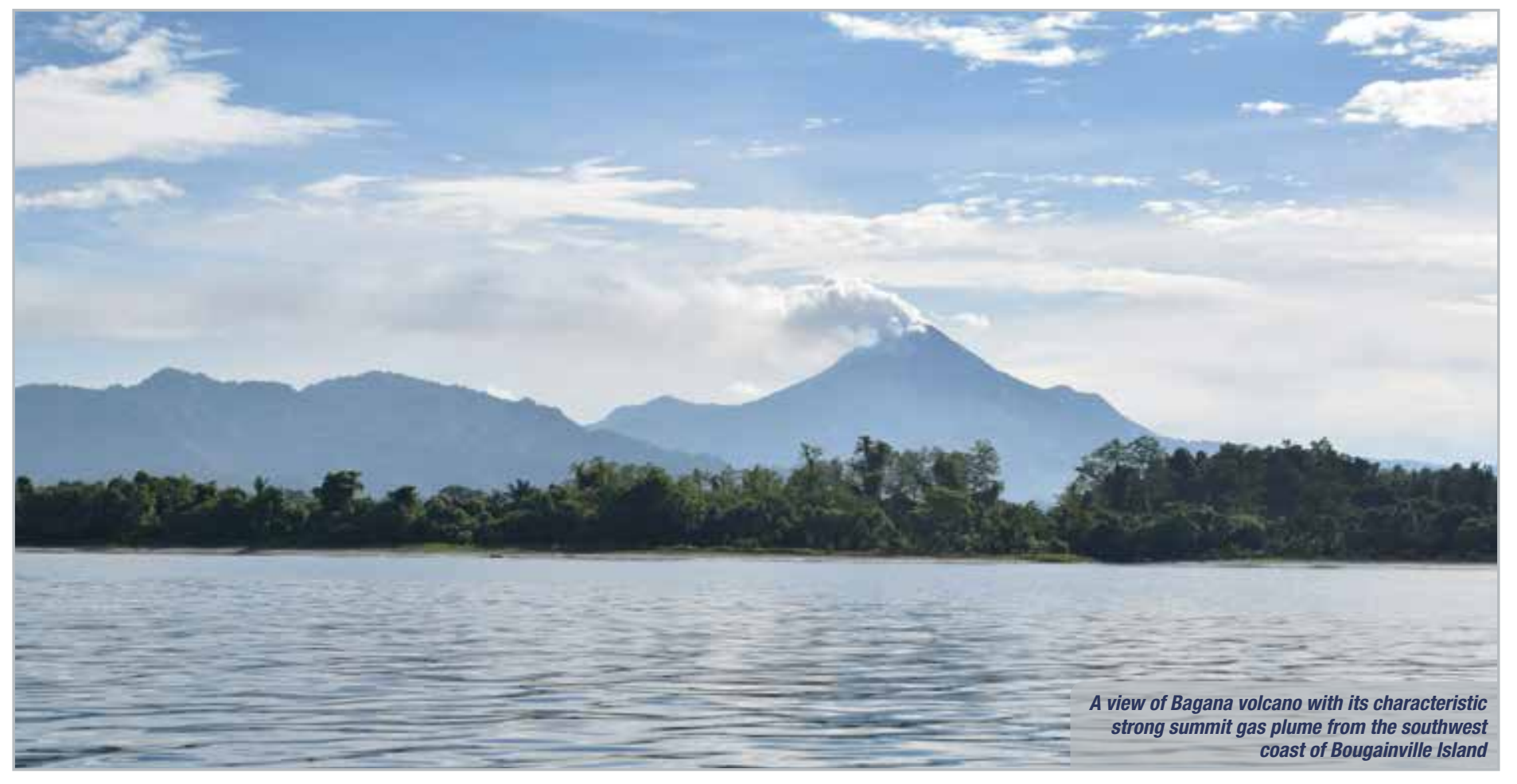

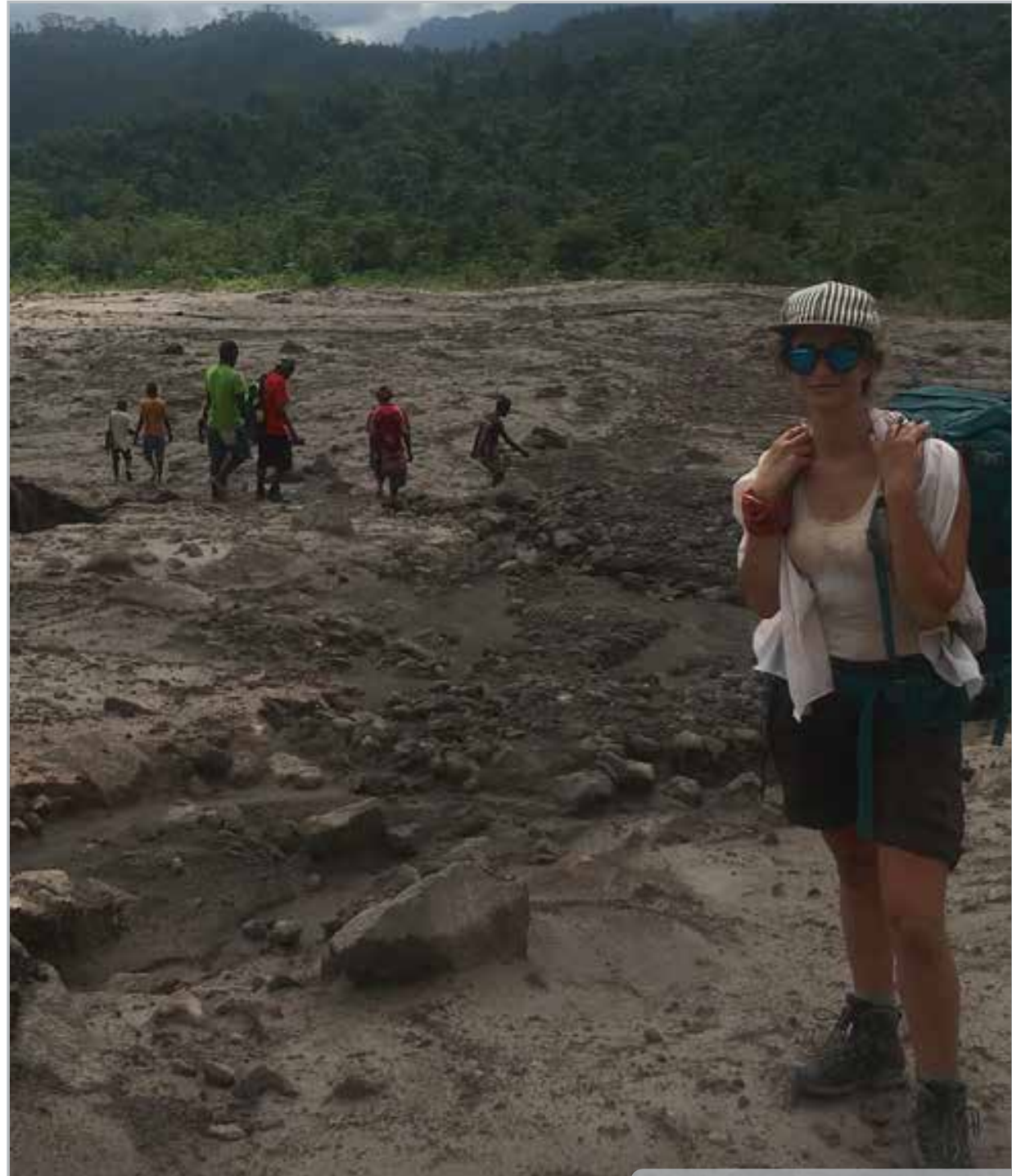

Lois Salem and our guides from Wakovi village make their way across the surface of a debris avalanche that recently covered the approaches to Bagana the volcano using cameras operating in the infrared and ultraviolet wavelengths. While the former gives information on the temperature of the lava flows, we use UV cameras to quantify sulfur dioxide gas emissions. Using another drone, this time with gas sensors on board, we made short flights through Bagana's gas plume to measure its chemistry. On two days, we trekked through the dense forest to reach the very foot of the volcano in order to collect samples of recently erupted lavas.

Working at the base of an active volcano is a hazardous pursuit and we were grateful for the advice of the villagers in Gotana, and Patsikopa and Wakovi, which lie even closer to Bagana's lower slopes. There was good reason to be cautious: an avalanche of volcanic debris, triggered by torrential rains, had recently swept down from high on the mountain and buried the surrounding countryside in metres of muddy ash and blocks of lava. Walking across this blasted landscape to reach the volcano, skirting the charred remains of ripped up trees, we were keenly aware that we could not be idle, but had to collect our samples quickly.

This was far from easy. Passing through the forest, we realised that small but swift-flowing streams around the base of the volcano were heated by subterranean geothermal activity, in places measuring as hot as $60^{\circ} \mathrm{C}$. We had to take extreme care fording these streams and avoiding the yellowish sulfurous mudflats on their banks. The lava flows themselves were 
steep, rubbly and unstable, and we picked our way tentatively around them to gather our samples, all too aware that even a minor sprain would make for a highly difficult march home. Fortunately, we were well guided by our companions, and returned safely to the village, heavily laden with chunks of dark, crystal-rich lava.

\section{A TROPICAL PARADISE}

Our work on Bagana was not just an enthralling scientific experience, though we collected a wealth of exciting new data and our lava samples, which are now being analysed in labs in Cambridge and Zurich. We were warmly welcomed and supported in the field by our hosts in the villages around Bagana and are hugely in their debt for guiding us through the forest to the volcano, frequently in torrential rain storms. Those long hours spent on the march made this expedition the most physically challenging I have undertaken but the beauty of our surroundings more than compensated. I saw hornbills in the wild for the first time, a mating pair that soared above us on the desolate plain below the volcano, and fruit bats that swept low through the banana and kaukau farms on the edge of Gotana village. Each exhausting day ended with our team bathing in the swift river that flowed through the village, listening to the whirr and click of immense numbers of insects and amphibians in the trees around us. For supporting this expedition and the research that has followed, I am deeply indebted to the Geological Society of London's Elspeth Matthews Fund, and my other funders the Deep Carbon Observatory and the NERC COMET programme.
Brendan McCormick Kilbride is a Research Associate in the Department of Earth Sciences, University of Cambridge, UK, and was a 2017 and 2018 recipient of the Geological Society of London's Elspeth Matthews Fund; e-mail: brendanvolc@gmail.com

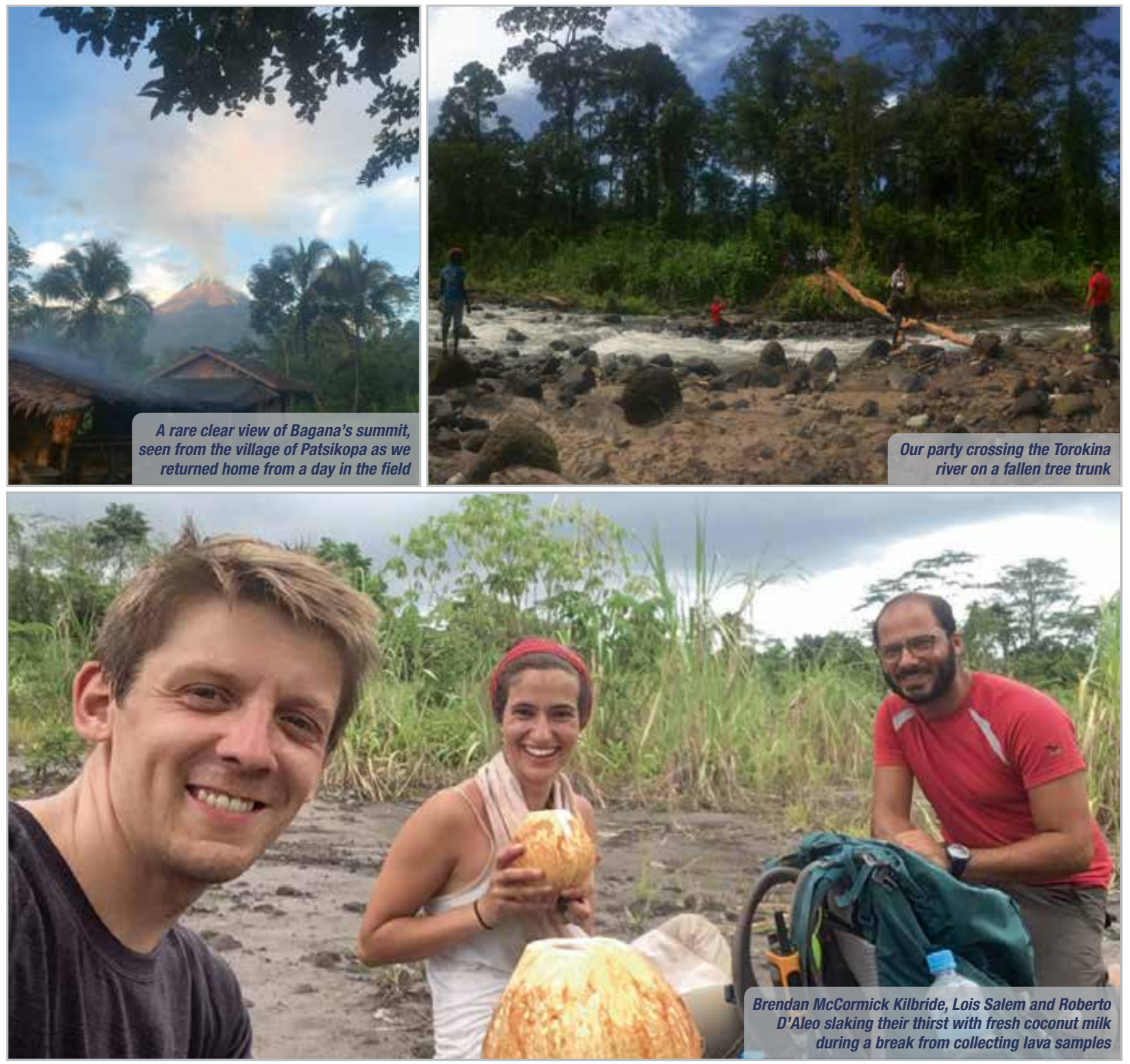

